\title{
PENDEKATAN KRITIK SENI TERHADAP DESAIN POSTER KARYA NAUFAN NOORDIYANTO
}

\author{
M. Edo Pratama Putra ${ }^{1)}$ Risvi Pangestu ${ }^{2)}$ Yosef Yulius ${ }^{3)}$ \\ ${ }^{12233}$ Program Studi Desain Komunikasi Visual, Universitas Indo Global Mandiri \\ Jl. Jend. Sudirman No.629 KM 4 Palembang Kode Pos 30129 \\ Email : kataedho1@gmail.com ${ }^{l)}$,risvipangestu@gmail.com ${ }^{21}$ yosef_dkv@uigm.ac.id ${ }^{3)}$
}

\begin{abstract}
Poster is a general term for a letter attached / placard. Posters are placards that are placed in public places, in the form of announcements or advertisements (Big Indonesian Dictionary, 1986: 679). Posters can be interpreted as a form of visual communication work for a wide audience in the format of writing and images, which are generally in the form of stickers on the wall with a communication range for the masses. This study analyzes the works of Naufan Noordiyanto's posters which include studies of the form of the work, design elements, messages and values contained in his poster works with an art criticism approach. Naufan Noordiyanto's poster works mostly on social and political themes, regarding identity, tolerance, equality, philosophy and things that are contemporary in nature. These works were created as a reflection of his experiences, thoughts, and current conflicts. Artist Naufan Noordiyanto has created many forms with changing forms. Many of the body parts that were deformed from the human figures he created appeared to be abnormal human forms. Of course, there is a message that designer Naufan Noordiyanto wants to convey through his works. As in his work, Marlina, which presents Naufan's self-disclosure of the consequences of a lack of equality for a person, and being isolated is sometimes preferable to being recognized through a set of norms in a system that can injure and negate. In this research, the writer uses mimesis theory, expressive theory, and objective / pragmatic theory.
\end{abstract}

Keywords: Posters, Art Criticism, Naufan Noordiyanto

\begin{abstract}
ABSTRAK
Poster merupakan istilah umum terhadap bentuk surat tempelan/ plakat. Poster merupakan plakat yang dipasang di tempat uтum, berupa pengumuman atau iklan (Kamus Besar Bahasa Indonesia, 1986: 679). Poster dapat dimaknai sebagai suatu bentuk karya komunikasi visual untuk khalayak luas dalam format tulisan dan gambar yang umumnya berupa tempelan di dinding dengan jangkauan komunikasi untuk massa. Penelitian ini menganalisis karya-karya poster Naufan Noordiyanto yang meliputi kajian tentang bentuk karya, unsur desain, pesan dan nilai-nilai yang terkandung di dalam karya posternya dengan pendekatan kritik seni. Karya poster Naufan Noordiyanto banyak mengangkat tema-tema sosial dan politik, mengenai identitas, toleransi, kesetaraan, filosofi dan hal -hal yang bersifat kontemporer. Karya-karya tersebut diciptakan sebagai refleksi dari pengalaman-pengalamannya, pemikirannya, dan konflik-konflik yang dihadapi pada saat ini.Seniman Naufan Noordiyanto banyak memunculkan wujud-wujud dengan perubahan bentuk. Banyak bagian-bagian tubuh yang dideformasi dari figur manusia yang diciptakannya terlihat menjadi wujud manusia yang abnormal. Tentunya terdapat pesan yang ingin disampaikan oleh desainer Naufan Noordiyanto melalui karya-karyanya. Seperti pada karyanya Marlina yang menyajikan pengungkapan diri Naufan tentang akibat-akibat yang timbul dari kurangnya kesetaraan atas diri seseorang, dan menjadi terasing kadang lebih disukai daripada untuk dapat dikenali melalui sekumpulan norma dalam suatu sistem yang dapat melukai dan meniadakan. Dalam penelitian ini penulis menggunakan teori mimesis, teori ekspresif, dan teori objektif/pragmatis.
\end{abstract}

Kata Kunci : Poster, Kritik Seni, Naufan Noordiyanto 


\section{Pendahuluan}

Pesatnya perkembangan teknologi digital pada era saat ini, menjadikan bentuk sajian komunikasi visual tumbuh semakin beragam. Segala bentuk media komunikasi visual diolah dan dirancang menjadi semakin menarik dan disesuiakan dengan target yang seleranya semakin beragam pula. Tidak terbatas pada penggunaan medianya, bahkan konten yang disajikan, bentuk, hingga gaya visual dan pendekatannya.

Salah satu media komunikasi visual yang sudah banyak berkembang adalah poster. Dari pertama kali muncul poster ditulis di atas panel kayu atau tembok di Yunani dan Italia, kemudian semakin berkembang pada tahun 1789 di Austria dari revolusi besar pengembangan teknik percetakan yang memungkinkan untuk produksi massal dan murah dengan teknik litografi yang diciptakan oleh Alois Senefelder, yang kemudian proses litografi berkembang hingga mampu mencetak 10.000 setiap jamnya (Ensiklopedia Indonesia, 1982: 62). Sejak saat itu poster memiliki peran dan diterapkan dalam banyak bidang. Tidak terbatas pada bidang akademis dan ilmiah, bahkan sampai saat ini banyak dipakai untuk keperluan komersial seperti iklan, promosi, politik dan sebagainya.

Ditinjau dari asal katanya poster merupakan istilah umum terhadap bentuk surat tempelan/ plakat. Poster merupakan plakat yang dipasang di tempat umum, berupa pengumuman atau iklan (Kamus Besar Bahasa Indonesia, 1986: 679). Poster dapat menjadi sebuah iklan sederhana yang dirancang untuk mempromosikan suatu hasil, pelayanan, nama atau gagasan, berbentuk kertas lembar, tercetak dan dipasang di tempat-tempat yang mudah terlihat banyak orang (Ensiklopedia Indonesia, 1982: 754).

Poster masuk pada batasan seni terapan karena fungsinya yang sangat terikat pada konsep sebagai media komunikasi publik. Sesuai dengan fungsi tersebut maka terciptalah strategi-strategi khusus yang dimaksudkan untuk mengoptimalkan kualitas dan keefektifan poster. Hal ini sebagaimana pendapat yang diberikan Ruswondho dan Syafi'i (1996: 4 dalam Nurlaili, 2009: 6) bahwa poster harusnya mampu menarik perhatian, menjangkau khalayak yang lebih luas atau spesifik, tahan lama, melengkapi program- program komunikasi yang lain, dapat dimanfaatkan untuk memenuhi kebutuhan kampanye tertentu dan murah untuk diproduksi.

Poster dapat dimaknai sebagai suatu bentuk karya komunikasi visual untuk khalayak luas dalam format tulisan dan gambar yang umumnya berupa tempelan di dinding dengan jangkauan komunikasi untuk massa. Poster berfungsi memberi informasi, motivasi, mengajak atau berupa himbauan untuk mempengaruhi masyarakat, dalam arti luas poster adalah iklan atau pengumuman yang diproduksi secara massal.

Poster sebagai media iklan bersifat sebagai iklan sederhana, jelas, dirancang untuk mempromosikan sesuatu hal, pelayanan/ gagasan. Media poster umunya berbentuk kertas lebar tercetak dipasang di tempattempat yang mudah dilihat oleh banyak orang (Peter Bridgewaler 1996: 56 dalam Nurlaili 2009: 7).

Adanya keunggulan dan fungsi dari poster ini, Penelitian ini akan menganalisis karya-karya poster Naufan Noordiyanto yang meliputi kajian tentang bentuk karya, unsur desain, pesan dan nilai-nilai yang terkandung di dalam karya posternya dengan pendekatan kritik seni. Karya poster Naufan Noordiyanto banyak mengangkat tema-tema sosial dan politik, mengenai identitas, toleransi, kesetaraan, filosofi dan hal -hal yang bersifat kontemporer. Karya-karya tersebut diciptakan sebagai refleksi dari pengalaman-pengalamannya, pemikirannya, dan konflik-konflik yang dihadapi pada saat ini.

Seniman Naufan Noordiyanto banyak memunculkan wujud-wujud dengan perubahan bentuk. Banyak bagianbagian tubuh yang dideformasi dari figur manusia yang diciptakannya terlihat menjadi wujud manusia yang abnormal. Tentunya terdapat pesan yang ingin disampaikan oleh desainer Naufan Noordiyanto melalui karya-karyanya. Seperti pada karyanya Marlina yang menyajikan pengungkapan diri Naufan tentang akibatakibat yang timbul dari kurangnya kesetaraan atas diri seseorang, dan menjadi terasing kadang lebih disukai daripada untuk dapat dikenali melalui sekumpulan norma dalam suatu sistem yang dapat melukai dan meniadakan. Dalam hal ini peneliti ingin mengetahui bagaimana pesan dan nilai-nilai sosial diwujudkan dalam bebrapa karya posternya.

Penulis akan mengkaji media poster melalui pengaplikasian tiga teori yaitu teori mimesis, ekspresif, dan objektif/pragmatis. Dengan tujuan untuk memberikan hasil analisis berupa pemahaman konsep terhadap media poster dalam desainkomunikasi visual. Sebab unsur yang terkandung di dalam poster memiliki berbagai macam makna dan tujuan komunikasi seperti poster yang memiliki unsur cerminan di dalam visualisasinya, visual yang mengedapankan simbol secara artistik dan poster yang memilki fungsi tersendiri bagi khalayak sasaran yang menjadi tujuannya.

\section{A. Fokus Masalah}

Berdasarkan uraian pada latar belakang masalah dapat difokuskan masalahnya pada bagaimana bentuk yang diciptakan, teori mimesis, ekspresif dan objektif/pragmatis, unsur-unsur desain, pesan yang dikandung, dan nilai-nilai yang muncul dari hasil interpretasi melalui pendekatan kritik seni terhadap karya poster Naufan Noordiyanto.

\section{B. Metode Penelitian}

Penelitian tentang pengaplikasian teori mimesis, ekspresif dan objektif/pragmatis pada media poster ini menggunakan penelitian kualitatif dengan pendekatan studi kasus. Sedangkan untuk mengumpulkan data, peneliti menggunakan pengamatan dan studi pustaka. Objek yang dipilih dalam penelitian ini adalah posterposter yang diterbitkan di akun Instagram Naufan 
Noordiyanto (@naufannoord) pada April-Desember 2018.

Dari seluruh terbitan pada April-Desember 2018, terdapat 130 terbitan yang terdiri dari foto, video, dan poster, Dari 130 terbitan tersebut, terdapat 64 terbitan poster, baik yang menggunakan teori mimesis, ekspresif maupun objektif/pragmatis. Setelah semua data terkumpul, peneliti melakukan analisis data dengan terlebih dahulu mengelompokkan poster yang menggunakan teori mimesis, teori ekspresif dan yang menggunakan toeri objektif/pragmatis. Pengelompokan ini didasarkan pada keterkaitan antara poster dengan teori yang digunakan. Hasil pengelompokan ini dapat menyeleksi sebanyak 19 poster menggunakan teori mimesis, 28 menggunakan teori eksrpresif, dan 17 poster yang menggunakan teori objektif/pragmatis.

Dari 64 poster yang menggunakan ketiga teori ini kemudian dianalisis lebih lanjut dengan mereduksi data hasil pengamatan melalui beberapa tahap seleksi untuk menjadi satu poster pada satu teori. Hasil dari reduksi data ini akan membantu peneliti dalam menemukan hasil aplikasi teori dalam beberapa poster yang digunakan.

\section{Pembahasan}

Dalam penelitian tentang pengaplikasian teori mimesis, ekspresif dan teori objektif/pragmatis, unsurunsur desain, pesan yang terkandung dan nilai yang muncul dari hasil interpretasi pada media poster dalam Desain Komunikasi Visual diperoleh beberapa poster yang menggunakan beberapa teori tersebut sebagai pendukung dalam menganalis poster, serta penjelasan mengenai hubungan/pandangan keempat teori tersebut dalam ilmu Desain Komunikasi Visual sehingga menjadi sebuah mapping theory. Mapping Theory bertujuan untuk membuat benang merah antara hubungan teori yang satu dengan teori yang lain, mensikapi/mengkritik teori dalam pandangan kebudayaan manusia.

Penyajian kritik seni memiliki bentuk dan cara yang sistematis. Dalam teori kritik seni dikenal empat tahap kegiatan, yaitu: deskripsi, analisis formal, interpretasi, dan evaluasi atau penilaian (Feldman dalam Mamannoor, 2002).

Pengaplikasian keempat teori di atas dianalisis melalui media poster dalam Desain Komunikasi Visual. Menurut Dina Indriyana (2011:62) Poster yaitu sajian kombinasi visual yang jelas, mencolok, dan menarik dengan maksud untuk menarik perhatian. Maksudnya suatu gambar dengan warna dan visual yang menarik dan mencolok dengan maksud digunakan desainer sebagai media untuk menyampaikan informasi, iklan atau sebuah ajakan sehingga dapat menarik perhatian khalayak dan mudah dipahaminya. Poster memiliki kekuatan untuk dicerna oleh orang yang melihat karena poster lebih menonjolkan kekuatan pesan, visual dan warna. Hal tersebut sesuai dengan pandangan Nana Sudjana (2005:51) bahwa poster adalah media yang kuat melalui warna, pesan, dan maksud untuk menangkap perhatian orang yang lewat, tetapi cukup lama menanamkan gagasan yang berarti dalam ingatannya. Poster dapat berupa gambar yang memiliki warna yang menarik sehingga dapat menangkap perhatian orang dengan menanamkan suatu makna tertentu yang ingin disampaikan desainer, sesuai dengan tujuan dari makna poster tersebut.

Poster merupakan media yang diharapkan mampu memotivasi tingkah laku orang yang melihatnya. Kustandi dan Sutjipto (2011: 50) menyebutkan bahwa poster merupakan media komunikasi yang efektif untuk menyampaikan pesan singkat, padat, dan imresif, karen ukurannya yang relatif besar.

Unsur atau elemen merupakan bagian dari suatu karya desain komunikasi visual termasuk poster. Unsurunsur tersebut saling berhubungan satu sama lain. Masing-masing memiliki sikap tertentu terhadap yang lain, misalnya sebuah garis mengandung warna dan juga memiliki style garis yang utuh, yang terputus-putus, yang memiliki tekstur bentuk, dan sebagainya. (Kusrianto, 2007, h.29) Selain itu juga dijelaskan oleh Arthur (2009), dalam suatu karya, unsur visual dapat tampil eksplisit atau implisit. Unsur yang tampil eksplisit berarti ia dapat langsung dikenali sebagai titik merah atau garis sapuan kuas misalnya. Sebaliknya, disebut implisit karena unsur-unsur ini tidak langsung dikenal sebagai garis atau titik, tapi ia tampil dalam bentuk gambar atau huruf. Unsur visual 'tersamar' atau 'terkandung' dalam bentuk gambar dan huruf. (h.20)

Poster memiliki semua unsur dalam desain komunikasi visual, namun di dalam sebuah poster juga memiliki teori yang dipakai dalam penggunaan visual, arti, dan pesan yang disampaikan. Teori-teori seperti mimesis, ekspresif dan objektif/pragmatis tidak hanya terdapat pada karya seni lukis, tetapi dalam media poster juga terdapat ketiga teori tersebut.

\section{A. Unsur-unsur desain}

\section{1) Garis}

Menurut Fajar Sidik (1981) yang dimaksud garis adalah suatu goresan, batas limit dari suatu benda, massa, warna, bidang dan ruang. Garis mempunyai dimensi memanjang dan mempunyai arah sera sifat-sifat seperti pendek, panjang, vertical, horizontal, diagonal, lurus, melengkung dan seterusnya.

Garis menurut Lilian Garret (dalam Sidik: 1981), merupakan unsur yang sangat penting dan menentukan dalam seni rupa. Garis dapat pula merupakan ruang garis (linier) negative atau garis virtual dengan panjang semuanya yang dibentuk oleh sambungan titik-titik optis yang bergerak cepat. Garis juga luas penggunaannya dalam komunikasi sebagaimana dalam simbol-simbol, kode-kode, juga digunakan para insinyur, arsitek, ahli ilmu pasti, kartografer, dan lain-lain.

Dari beberapa pendapat tentang pengertian garis, maka dapat disimpulkan bahwa garis adalah suatu goresan untuk membentuk suatu objek atau batas limit dari suatu benda, masa dan ruang.

\section{2) Bentuk}

Pengertian bentuk dalam buku Diksi Rupa diartikan sebagai bangun, gambaran, rupa, wujud atau sistem 
(Susanto: 2012). Sedangkan istilah bentuk dalam bahasa Inggris diartikan sebagai form atau shape. Shape adalah suatu bidang kecil yang terjadi karena dibatasi oleh sebuah kontur (garis) atau dibatasi oleh adanya warna yang berbeda atau oleh gelap terang pada arsiran atau karena adanya tekstur.

Menurut Kartika (2004: 42), shape dibagi menjadi shape yang menyerupai wujud alam atau representatif (figur) dan shape yang tidak sama sekali menyerupai wujud alam (non figur). Di dalam pengolahan objek akan terjadi perubahan wujud sesuai dengan selera maupun latar belakang sang seniman. Perubahan wujud tersebut antara lain: stilisasi, distorsi, transformasi dan disformasi. Stilisasi merupakan cara penggambaran untuk mencapai bentuk keindahan dengan cara menggayakan objek atau benda yang digambar, yaitu dengan menggayakan setiap kontur pada objek atau benda tersebut.

\section{3) Warna}

Pengertian warna menurut Fajar Sidik dan Aming. P (1981), warna dalam ilmu bahan adalah berupa zat warna atau pigmen. Sedangkan menurut Susanto (2012: 433), warna didefinisikan sebagai getaran atau gelombang yang diterima indera penglihatan manusia yang berasal dari pancaran cahaya melalui sebuah benda.

\section{4) Ruang}

Ruang adalah bentuk dua dimensional atau tiga dimensional bidang dan keluasan. Ruang mempunyai dimensi memanjang, melebar dan kedalaman. Ruang jika diartikan secara fisik adalah rongga yang terbatas maupun tidak terbatas. Ruang dapat dibagai menjadi dua yaitu ruang fisik atau ruang nyata (actual) dan ruang ilusif. Ruang nyata terlihat pada seni tiga dimensi sedangkan ruang ilusif seperti dalam seni lukis pemandangan dan pemakaian perspektif (Susanto, 2012: 338).

\section{5) Tekstur}

Tekstur mempunyai arti nilai raba suatu permukaan benda baik nyata maupun semu. Tekstur dapat melukiskan sebuah permukaan objek, seperti kulit, rambut, kayu, plastik, kaca dan bisa merasakan kasar halusnya, keras lunaknya, teratur tidaknya suatu permukaan objek. Dalam perwujudannya tekstur ada dua macam yaitu tekstur nyata dan tekstur semu. Tekstur nyata ialah nilai raba suatu permukaan bila diraba secara fisik betul-betul terasa beda sifatnya. Sedangkan tekstur semu ialah nilai raba suatu permukaan bila diraba secara fisik tidak terasa perbedaan. Bila dilihat mata tampak perbedaan gelap terang dan perbedaan tinggi rendahnya permukaan.

\section{B. Teori Mimesis}

Teori mimesis adalah Representasi atau imitasi menirukan suatu objek/ alam sesuai dengan aslinya. Mimesis juga dapat diartikan sebagai suatu teori yang dalam metodenya membentuk suatu karya dengan didasarkan pada kenyataan kehidupan sosial yang dialami dan kemudian dikembangkan menjadi suatu karya dengan penambahan skenario yang timbul dari daya imajinasi dan kreatifitas seniman dalam kehidupan nyata tersebut.

"Mimesis berasal bahasa Yunani yang berarti tiruan. Dalam hubungannya dengan kritik sastra mimesis diartikan sebagai pendekatan sebuah pendekatan yang dalam mengkaji karya sastra selalu berupaya untuk mengaitkan karya sastra dengan realitas atau kenyataan. Perbedaan pandangan Plato dan Aristoteles menjadi sangat menarik karena keduanya merupakan awal filsafat alam, merekalah yang menghubungkan antara persoalan filsafat dengan kehidupan" (Ravertz, 2007: 12).

Plato menganggap bahwa karya seni berada di bawah kenyataan karena hanya berupa tiruan dari tiruan yang ada di pikiran manusia yang meniru kenyataan. Sedangkan Aristoteles menganggap karya seni adalah berada di atas kenyataan karena karya seni sebagai katalisator untuk mensucikan jiwa manusia. Dalam desain komunikasi visual, teori mimesis juga banyak diterapkan oleh desainer dengan memberikan visual berupa objek tiruan sesuai dengan realitas yang ada, penggunaan teori mimesis ini banyak dipakai untuk periklanan, promosi, informasi ataupun penggambaran objek yang diharuskan mirip dengan bentuk aslinya.

Contoh karya poster terdapat teori mimesis di dalamnya adalah karya poster oleh Naufan Nooediyanto (April-Desember 2018) sebagai berikut:



Gambar 1: Poster bertema "Penolakan terhadap perbudakan wanita" oleh Naufan Noordiyanto 8 Desember 2018 (Teori Mimesis dan Ekspresif). (Sumber: Instagram @ naufannoord) 




Gambar 2: Poster bertema "\#Reggae, the struggle music for dignity" oleh Naufan Noordiyanto 7 November 2018 (Teori Mimesis dan Ekspresif).

(Sumber: Instagram @naufannoord)

Poster pada gambar pertama menggunakan teori mimesis dan ekspresif dan sedikit objektif/pragmatis di dalamnya, terdapat ilustrasi visual berupa patung liberty yang merupakan bentuk tiruan dari realitas patung liberty. Kemudian dari desainer memasukkan teori ekspresif sehingga patung liberty dibentuk dengan gestur terlantar sehingga ekspresi desainer terlihat. Dan penambahan simbol barcode menambahkan karya poster ini memiliki kegunaan dan fungsi yang termasuk ke dalam teori objektif/pragmatis.

Poster pada gambar kedua menggunakan teori mimesis dan ekspresif di dalamnya, teori mimesis pada poster ini berupa bentuk visual yang menyerupai binatang singa. Pengolahan visual singa yang digabungkan dengan berbagai bentuk alat musik seperti piano, gitar dan lain sebagainya merupakan ekspresi dari desainer.

\section{Teori Ekspresif}

Teori ekspresif adalah teori yang menitik beratkan pada ekspresi estetik, ekspresi jiwa, perasaan dari penciptanya/senimannya. Lebih jauhnya teori ini memandang seberapa jauh niatan seniman tertuang dalam karya seni. Dalam teori ekspresif ini maksud dan perasaan seniman menjadi penentu dalam proses analisis dan interpretasi atas karya (Abrams, 1978: 17).

Karya seni merupakan karya yang kreatif dan imajiner dan dimaksudkan untuk menghadirkan keindahan. Dalam kaitan ini, Esten menyatakan bahwa ada dua hal yang harus dimiliki oleh seorang seniman, yakni: daya kreatif dan daya imajinatif. Daya kreatif adalah daya untuk menciptakan hal-hal yang baru dan asli. Manusia penuh dengan seribu satu kemungkinan tentang dirinya. Untuk itu, seorang seniman berusaha memperlihatkan kemungkinan tersebut, memperlihatkan masalah-masalah manusia yang substil (halus) dan bervariasi dalam karya-karya seninya. Sedangkan daya imajinatif adalah kemampuan seniman untuk membayangkan, mengkhayalkan, dan menggambarkan sesuatu atau peristiwa.

Seorang seniman yang memiliki daya imajinatif yang tinggi bila mampu memperlihatkan dan menggambarkan kemungkinan-kemungkinan kehidupan, masalah, dan pilihan alternatif yang mungkin dihadapi manusia. Kedua daya itu akan menentukan berhasil tidaknya suatu karya seni (Abrams, 1978 : 9). Jadi, teori ekspresif adalah pendekatan yang didasarkan pada desainer itu sendiri, baik kaitannya dengan pikiran, sudut pandang serta imajinasinya terhadap karya desain yang diciptakannya. Dalam desain komunikasi visual teori ekspresif dapat diterapkan oleh seorang desainer dalam karya desain dengan mengedepankan ekspresi dari desainer melalui ilustrasi atau objek visual yang diolah sesuai keinginan dan ekspresi desainer itu sendiri.

Contoh karya poster terdapat teori ekspresif di dalamnya adalah karya poster oleh Naufan Noordiyanto (April-Desember 2018) sebagai berikut:

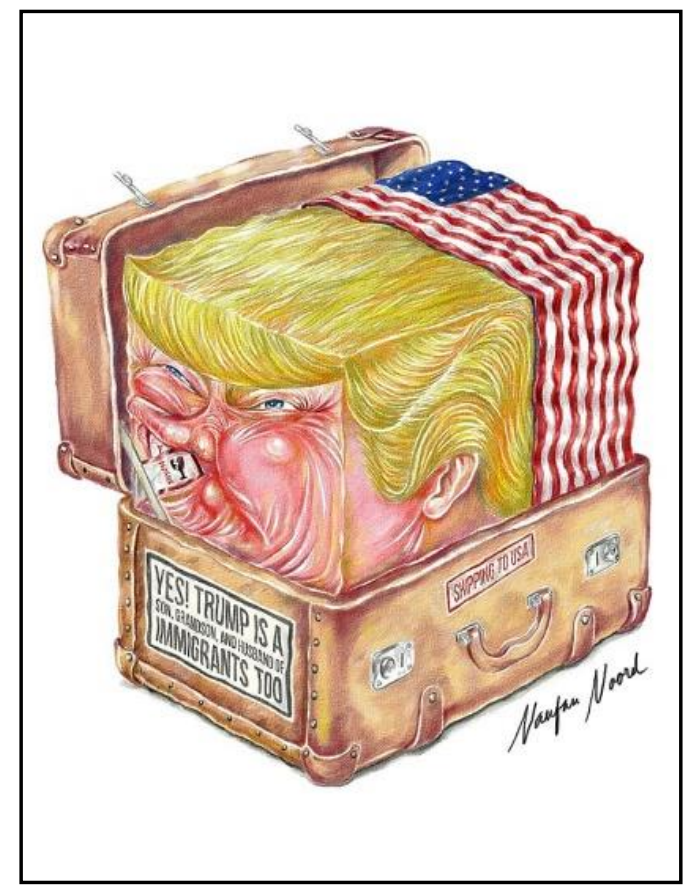

Gambar 3: Poster bertema "Fight against \#Trump's \#Travel/immigration Ban" oleh Naufan Noordiyanto 6 April 2018 (Teori Ekspresif). (Sumber: Instagram @ naufannoord) 


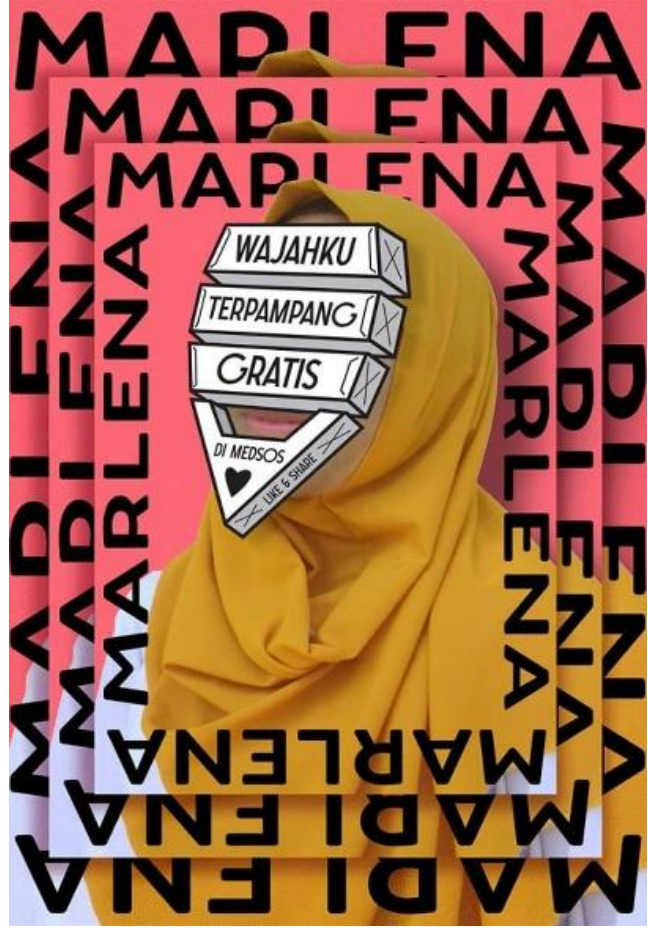

Gambar 4: Poster bertema "wajah Marlena milik (dinikmati) umum" oleh Naufan Noordiyanto 10

Desember 2018 (Teori Ekspresif).

(Sumber: Instagram @naufannoord)

Poster pada gambar ketiga menggunakan teori ekspresif dan sedikit objektif/pragmatis di dalamnya, terdapat ilustrasi visual berupa wajah Donald Trump yang dibentuk sedemikian rupa dengan tambahan visual koper menambah ekspresi desainer dalam menyampaikan pesan yang ingin disampaikannya. Poster ini merupakan perasaan atau ekspresi sang desainer terhadap sosok Donald Trump, dengan mengungkapkan melalui penampilan visual desain poster yang ekspresif. Poster tersebut selain merupakan ekspresi sang desainer juga merupakan suatu kampanye dalam melawan suatu hal, dengan tujuan untuk mendorong khalayak dan mempengaruhi masyarakat terhadap pendapat yang dia gambarkan melalui visual pada poster.

Sedangkan poster pada gambar keempat menggunakan teori ekspresif di dalamnya, hal ini dapat terlihat dari penggunaan visual yang dipakai oleh desainer. Wajah asli perempuan di eksresikan dengan objek-objek tambahan yang membantu dalam menyampaikan ekspresi desainer, Ekspresi desainer melalui poster ini juga sebagai bentuk aksi dan perasaan desainer terhadap kasus sosial yang sering terjadi di masyarakat.

Teori ekspresif sangat berpengaruh dalam desain komunikasi visual dalam upaya penyampian pesan yang ingin disampaikan, ekspresi dari desainer dapat membuat daya ganggu yang tinggi sehingga menyebabkan ketertarikan dari khalayak untuk memahami pesan yang disampaikan. Karya teori eksresif dalam desain komunikasi visual juga menekankan hal yang bersifat fungsional karena tujuan utama pembuatan poster adalah untuk menarik sebanyak-banyaknya khalayak sasaran.

\section{Teori Objektif/Pragmatis}

Teori objektif/pragmatis adalah memandang ciptaan seni sebagai sesuatu yang dimaksudkan untuk tujuan tertentu yang berhubungan dengan penikmatnya. Kegunaan dan fungsi menciptakan seni untuk tujuan tertentu, kemanfaatan karya seni yang diciptakan. Dengan tujuan agar bisa berupa santapan estetis kepuasan batin/psikis, kenikmatan/kemanfaatan fisik (usefull, applied) maupun tujuan-tujuan fungsional yang berkaitan dengan nilai, norma. Penilaian terhadap seni hendaknya dihubungkan dampaknya terhadap penikmat atau khalayak sasaran.

Dalam desain komunikasi visual, teori objektif/pragmatis sangat dibutuhkan, karena tujuan dari ilmu desain komunikasi visual adalah untuk mengedepankan penyampaian informasi dan nilai fungsi di dalamnya. "Desain komunikasi visual merupakan sebuah karya desain yang mengkomunikasikan informasi dan pesan yang ditampilkan secara visual" (Cenadi, 1999:3).

Sedangkan Handrawati dan Ardjaka, (1991:38) menjelaskan bahwa Desain Komunikasi Visual merupakan suatu disiplin ilmu yang mempelajari segala sesuatu yang berkaitan dengan media komunikasi (terutama media komunikasi visual) dan media komunikasi visual tersebut haruslah memuat segala macam informasi yang akan disampaikan kepada komunikan dalam hal ini masyarakat umum sebagai konsumen dan target audiens. Maka dari itu teori objektif/pragmatis adalah merupakan bagian dari desain komunikasi visual itu sendiri, karena dalam desain nilai fungsional sangat diutamakan dalam menciptakan karyakarya desain.

Secara lebih khusus dalam media poster, teori objektif/pragmatis terdapat dalam bentuk penyampian pesan dan informasi yang disampaikan. Poster yang mempunyai nilai fungsi adalah yang dapat diterima oleh khalayak sasaran sehingga poster yang diciptakan memiliki manfaat untuk khalayak yang menjadi sasarannya.

Teori obyektif/pragmatis memiliki keindahan atau ciri-ciri yang menciptakan nilai estetika yang memang telah melekat pada sebuah poster yang indah, terlepas dari orang yang mengamatinya. Pengamatan seseorang hanyalah menemukan atau menyingkapkan sifat-sifat indah yang sudah ada pada sebuah poster dan sama sekali tidak berpengaruh untuk mengubahnya. Yang menjadi persoalan dalam teori ini ialah ciri-ciri khusus manakah yang membuat sebuah poster menjadi indah atau dianggap bernilai estetis.

Contoh karya poster terdapat teori objektif/pragmatis di dalamnya adalah karya poster oleh Naufan Nooediyanto (April-Desember 2018) sebagai berikut: 


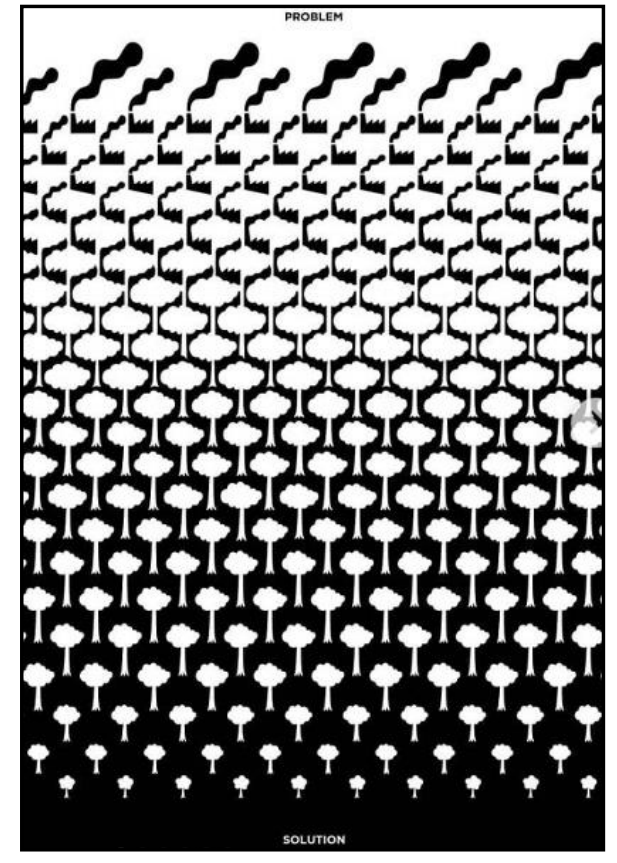

Gambar 5: Poster bertema "Trees VS Industrial Carbon Emissions" oleh Naufan Noordiyanto 3 November 2018 (Teori Objektif/Pragmatis).

(Sumber: Instagram @naufannoord)

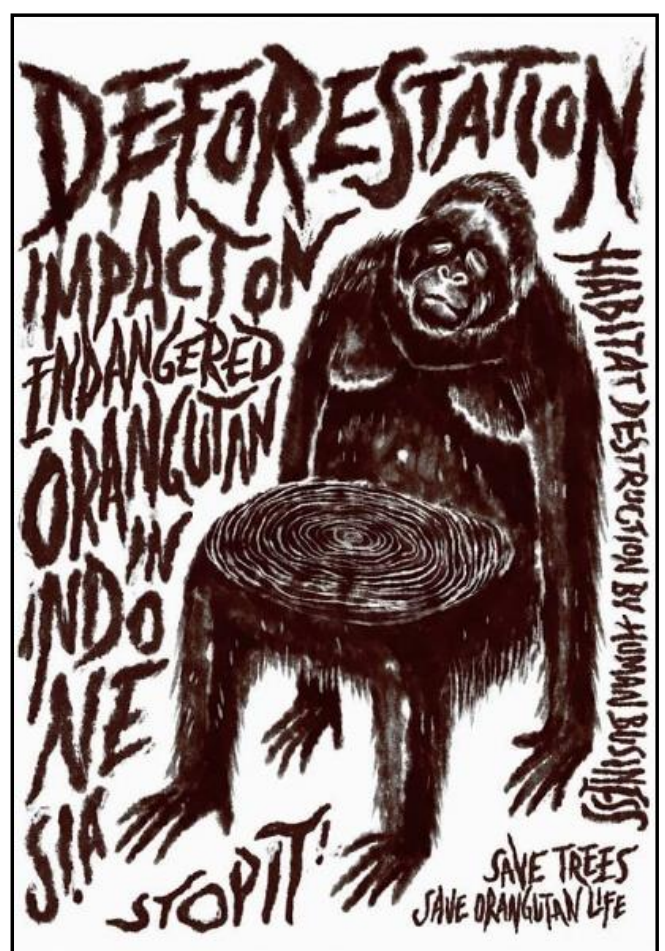

Poster 6: Poster bertema "Save trees, save \#orangutan life" oleh Naufan Noordiyanto 26 Desember 2018 (Teori Objektif/Pragmatis). (Sumber: Instagram @naufannoord)
Poster pada gambar kelima menggunakan teori objektif/pragmatis di dalamnya, terdapat bentuk visual batang pohon dan asap pabrik yang disederhanakan. Poster ini memiliki nilai fungsional yang tinggi, yaitu desainer memberikan informasi penting atau informasi mengenai kejadian sosial di sekitar masyarakat. Dengan adanya poster ini, desainer memberikan manfaat kepada target audiens melalui media poster. Poster ini tidak hanya untuk dinikmati keindahan estetis, visual, warna, dan layoutnya saja, tetapi dapat diambil nilai-nilai, pesan dan fungsi dari visual yang disampaikan. Sehingga dapat menggerakan target audiens untuk membuat tindakan atau nilai kebermanfaatan dalam menuntaskan permasalahan sosial yang terjadi.

Sedangkan poster pada gambar keenam menggunakan teori objektif/pragmatis yang sama dengan poster sebelumnya, di dalam poster lebih mengedepankan fungsi dan manfaat yang terkandung di dalamnya. Sehingga tujuan yang ingin disampaikan dapat diterima oleh target audiens, adanya objek atau simbol orang utan pada poster memberikan visual yang tepat terhadap pesan dari desainer, dengan tambahan visual berupa potongan pohon menjadikan nilai dalam poster lebih memiliki nilai dan norma. Hal ini dapat menggerakkan target audiens setelah melihat pesan dari poster ini, kebermanfataan yang dihasilkan sangat besar dan mempunyai pengaruh yang besar juga pada khalayak sasaran.

\section{E. Tahapan Kritik Seni}

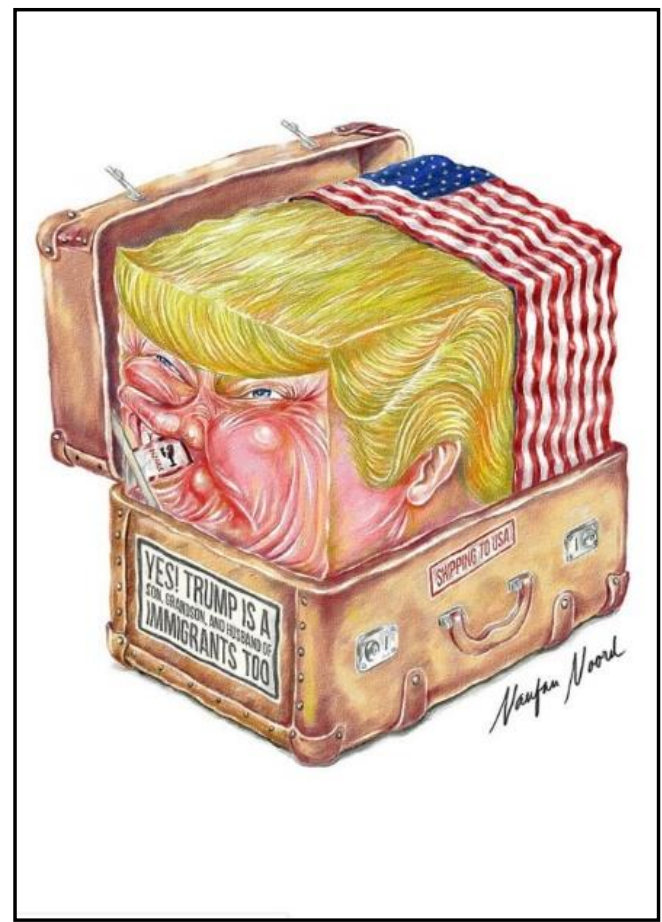

Gambar 7: Poster bertema "Fight

against \#Trump's \#Travel/immigration Ban"

oleh Naufan Noordiyanto 6 April 2018.

(Sumber: Instagram @naufannoord) 
1) Deskripsi

Poster ini merupakan karya yang menggunakan media digital dengan teknik drawing. Bagian karya ini menampilkan subjek material dengan bentuk figuratif yaitu sosok Donald Trump yang sedang berada di dalam sebuah koper. Terlihat Donald Trump di bagian paling atas dengan wajah berbentuk kotak. Terlihat bendera Amerika Serikat yang melilit tubuh Donald Trump bagian belakang. Di antara sosok Dolad Trump dan lilitan bendera tersebut sebuah koper berwarna kecokelatan yang mewadahi kedua objek tersebut dengan terdapat teks/pesan di luar koper. Dan terdapat penambahan bendera dengan ikon fragile di bagian mulut sosok Dolad Trump. Naufan memposisikan dan menggambarkan materi subjeknya secara tidak formal, dan bahkan dengan suatu cara pandang yang berbeda terhadap sesuatu yang dilihatnya dan dialaminya, dalam latar belakang karya ini Naufan dengan objek lahir dari budaya yang berbeda yaitu budaya Indonesia dan budaya Amerika.

\section{2) Analisis Formal}

Untuk menjelaskan tentang unsur-unsur desain dalam karya ini dan pengorganisasiannya digunakan konsep analisis bentuk. Pada karya poster Naufan Noordiyanto (2018) yang bertema "Fight against \#Trump's \#Travel/immigration Ban", terdapat unsur-unsur sebagai berikut:

Tabel 1: Analisis Unsur-unsur Desain Karya Poster

\begin{tabular}{|l|l|l|}
\hline No & $\begin{array}{l}\text { Unsur- } \\
\text { Unsur } \\
\text { Desain }\end{array}$ & Penerapan \\
\hline 1 & Bentuk & $\begin{array}{l}\text { - Bentuk figuratif dan objek berupa } \\
\text { orang manusia, bendera, dan } \\
\text { sebuah koper, } \\
\text { Terdapat deformasi bentuk pada } \\
\text { wajah }\end{array}$ \\
\hline 2 & Warna & $\begin{array}{l}\text { Koper menggunakan warna } \\
\text { kecokelatan, Sosok Donal Trump } \\
\text { dengan warna rambut kuning, dan } \\
\text { bendera Amerika sesuai warna } \\
\text { aslinya. }\end{array}$ \\
\hline 3 & Tekstur & Nyata \\
\hline 4 & Ruang & Semu \\
\hline
\end{tabular}

Dilihat dari unsur bentuk, pada bagian poster ini terdapat perubahan bentuk pada wajah figur laki-laki yaitu berupa distorsi wajah Donald Trump menjadi kotak mengikuti bentuk koper. Bentuk tersebut dianalisa sebagai bentuk dari bagian isi koper (persegi panjang) atau kotak. Bentuk koper tersebut menginspirasi Naufan dalam penciptaan wajah Donald Trump dalam karyanya. Visualisasi objek tersebut merupakan gaya yang mendistorsi wujud wajah manusia menjadi bentuk sebuah objek.
Menurut Kartika (2004), di dalam pengolahan objek akan terjadi perubahan wujud sesuai dengan selera maupun latar belakang sang desainer. Perubahan wujud tersebut antara lain: stilisasi, distorsi, transformasi dan disformasi. Distorsi merupakan penggambaran bentuk yang melebih-lebihkan atau menonjolkan bentuk-bentuk aslinya. Dalam hal ini Naufan Noordiyanto mendistorsikan bentuk wajah Donald Trump menjadi kotak sesuai dengan objek koper. Perubahan tersebut begitu jelas dan bervolume.

\section{3) Interpretasi}

Dalam poster ini Naufan Noordiyanto menggambarkan sebuah kritik dalam politik. Hal tersebut ditunjukkan pada wujud karya berupa figur lakilaki yang dianalisa sebagai perwujudan Donald Trump yang berkedudukan sebagai Presiden Amerika Serikat. Objek bendera yang dianalisa sebagai Bendera Amerika Serikat. Sedangkan objek koper berisikan teks/pesan berupa "Yes! Trump is a son, grandson, husband, of Immigrants too".

Perwujudan wajah Donald Trump yang di distorsi menjadi bentuk kotak dari objek koper menunjukkan bagaimana keputusan dari Donald Trump mempengaruhi pemikiran dan imajinasinya. Naufan memiliki jiwa sosial dan aktivis yang tinggi dalam mengkritik fenomena sosial terutama politik, dan khususnya peraturan Imigran dari Donald Trump di Amerika Serikat yang dianalisa sebagai bentuk yang menginspirasi dan kemudian mendistorsi pada wajah Donald Trump dalam karya "Fight against \#Trump's \#Travel/immigration Ban". Dengan bentuk-bentuk yang didistorsi Naufan ingin mendiskusikan tentang manakah sesuatu yang real dan an real artinya membedakan antara persepsi dan realita. Bentuk yang didistorsi dimaknai sebagai kondisi sosial yang menganggap atau menilai suatu hal dikatakan ideal dan tidak ideal.

Fenomena imigrasi yang dilarang masuk di Amerika Serikat oleh Presiden Donald Trump yang banyak mendapat penolakan karena dapet memisahkan antara anak dan orang tuanya. Hal ini menjadi gambaran karakter dari Donald Trump yang sangat keras dan angkuh terhadap para imigran yang berada di negaranya. Karya ini sebagai gambaran kritik penolakan terhadap keputusan Donald Trump yang banyak menuai kontroversi, terlebih lagi sosok Donald Trump sendiri adalah merupakan sosok yang terlahir dari keluarga imigran juga. Hal seperti ini dianggap sebagai sebuah kekangan dan beban bagi semua orang yang digambarkan oleh Naufan menjadi isi padat yang terdapat di dalam koper. Menurut pandangan Naufan, koper sangat identik dengan kasus imigrasi tersebut.

Dari latar belakang dan interpretasi karya kita dapat mengetahui nilai sosial yang dikandung, seperti pada latar belakang Donald Trump dan keputusannya terhadap para Imigran. Pesan yang terkandung adalah bahwa semua manusia semestinya memiliki kebebasan, hak asasi manusia, saling menghormati dan menghargai sesamanya, meskipun berbeda budaya. Manusia 
memiliki hak kedudukan atau keadilan sosial yang sama dan tidak diukur dari perbedaan-perbedaan yang ada.

\section{4) Evaluasi}

Karya poster ini mengingatkan peneliti pada karyakarya Digital Imaging yang bergerak dalam kampanye sosial masyarakat, hanya saja dalam penciptaannya Naufan menggunakan teknik lain yaitu drawing di dalam poster. Hal ini memperlihatkan bagaimana budaya Indonesia tidak terlepas dari pribadi Naufan Noordiyanto, dalam pengakuannya ia tidak setuju dengan adanya pengelompokan, menurutnya seni bersifat universal dengan tidak mengkotak-kotak dari mana asal budayanya.

Naufan Noordiyanto menggunakan simbol subjektifnya dalam penciptaan wajah Donald Trump yaitu dengan anggapan kekangan identik dengan kesesakan di dalam koper yang sempit, namun menurut pandangan peneliti tidak semua orang mempunyai persepsi yang sama tentang sebuah kesesakan atau kekangan. Pada sosok Donald Trump merupakan kreatifitas Naufan dalam mewujudkan ide atau gagasannya. Jika dibandingkan dengan karya lainnya seperti pada karyanya yang lain, karya ini terlihat lebih tidak normal dengan bentuk-bentuk yang diciptakannya karena dalam karya yang lain Naufan banyak menggunakan bentuk-bentuk yang stilasi sedangkan pada poster ini terdapat distorsi bentuk pada wajah lakilaki. Dilihat dari bahan material yang digunakan, karya poster ini Naufan menggunakan teknik drawing di dalam sebuah poster digital.

\section{Kesimpulan}

Desain komunikasi visual adalah ilmu yang mempelajari tentang proses pengkomunikasian kepada

\section{Daftar Pustaka}

Abrams, M.H. 1971. The Mirror and The Lamp Romantic Theory and The Critical Tradition. Oxford University: Press.

Kusuma, Yuliandi. 2009. Trik Paten Poster Keren. Jakarta: Grasindo.

Sudjana, Nana. 2005. Metoda Statistika. Bandung: Tarsito.

Sutjipto, Bambang. 2011. Media Pembelajaran Manual dan Digital. Bogor: Ghalia Indonesia.

Tinarbuko, S. 2015. Desain Komunikasi Visual Penanda Zaman Masyarakat Global. Yogyakarta: CAPS (Center for Academic Publishing Service).

Internet:

Ardwi. 2010. Poster. http://ardwi.wordpress.com /2019/03/01/ poster/,online (diakses tanggal 1 Maret 2019) masyarakat melalui budaya visual, salah satu upaya komunikasi adalah melalui media poster. Poster merupakan salah satu media yang efektif untuk menyampaikan sebuah pesan, informasi, iklan, berita dan kampanye dalam bentuk sosial. Dalam proses penyampaiannya, poster memiliki beberapa teori yang digunakan diantaranya adalah unsur-unsur desain, teori mimesis, teori ekspresif, dan teori objektif/pragmatis.

Teori mimesis di dalam poster menjadi salah satu unsur yang banyak digunakan oleh seorang desainer, teori ini digunakan untuk menyampaikan informasi atau pesan yang mengharuskan menampilkan objek visual sesuai dengan realitasnya seperti bentuk patung liberty atau pun binatang singa. Tiruan dari objek aslinya dapat dilakukan dalam media poster, sehingga target audiens mampu memahami dan mengerti objek yang dimaksud oleh desainer.

Teori ekspresif di dalam poster merupakan bentuk ekspresi, perasaan, ungkapan dari desainer terhadap sesuatu yang ingin disampaikan. Ekspresi objek visual tidak harus berbentuk tiruan dari objek aslinya, namun lebih membebaskan desainer dalam menggambarkan bentuk visual yang ingin disampaikan. Poster yang memakai teori ekspresi ini dapat memberikan luapan emosi desainer atau permintaan klien terhadap suatu permasalahan sosial, sehingga tidak ada tuntutan dalam visual yang harus digunakan.

Sedangkan teori objektif/pragmatis pada media poster adalah tujuan dari diciptakannya poster itu sendiri, poster yang menggunakan teori objektif/pragmatis lebih mengedepankan nilai fungsional ataupun kebermanfatan dari diciptakannya poster tersebut, penggunaan objek visual yang disampaikan pun harus memiliki daya paham yang tinggi dan dapat diterima sehingga tidak hanya untuk dinikmati tetapi juga untuk dimengerti. 